Case Reports

\title{
5-Azacytidine in Chronic Myelomonocytic Leukemia: Case Report and Review of Literature.
}

Greco M., Criscuolo M., Fianchi L., Fabiani E., Pagano L. and Voso MT.

Istituto di Ematologia, Università Cattolica Sacro Cuore, Rome, Italy

Correspondence to: Dott.ssa Maria Teresa Voso. Università Cattolica Sacro Cuore, Largo A. Gemelli 8, 00168

Rome, Italy. Tel.: +39 0630154180; Fax: +39 0635503777. E-mail: mtvoso@ rm.unicatt.it

Competing interests: The authors have declared that no competing interests exist.

Published: March 15, 2011

Received: January 12, 2011

Accepted: March 03, 2011

Mediterr J Hematol Infect Dis 2011, 3: e2011011, DOI 10.4084/MJHID.2011.011

This article is available from: http://www.mjhid.org/article/view/7839

This is an Open Access article distributed under the terms of the Creative Commons Attribution License (http://creativecommons.org/licenses/by/2.0), which permits unrestricted use, distribution, and reproduction in any medium, provided the original work is properly cited.

Hypomethylating drugs are useful in the management of Myelodysplastic syndromes, but there are only few reports on chronic myelomonocycitic (CMML) leukemia patients. We describe our experience in 3 CMML patients treated with azacitidine. Two patients obtained partial response after 4 treatment cycles with only minor toxicity and are in continuous partial response, with stable peripheral blood counts, at 29 and 30 cycles from treatment start.

Introduction: Chronic myelomonocytic leukemia (CMML) is a clonal disorder of hematopoietic stem cells often occurring in elderly patients. It was originally classified by the French-American-British (FAB) working group as a myelodysplastic syndrome characterized by monocytosis (> 1000/microl), bone marrow monocyte infiltration, blast cells less than $5 \%$ in the peripheral blood and less than $30 \%$ in the bone marrow. ${ }^{1}$ In the new WHO classification system of tumors of hematopoietic and lymphoid tissues, CMML has been reclassified as a myelodysplastic/myeloproliferative diseases, a hybrid disorder characterized by proliferation of the myeloid series and dysplasia of erythroid-megakaryocytic series. CMML has been subdivided in the WHO classification in two subclasses according to prognosis, blood and bone marrow blast count: CMML-1: $<5 \%$ blasts and $5-9 \%$ blasts in peripheral blood and bone marrow, respectively, and CMML-2: $<10 \%$ blasts and
$10-19 \%$ blasts in peripheral blood and bone marrow, respectively. $^{2}$

CMML is a very hard disease to treat and the prognosis is quite variable, with a median survival of about 20 months. Patients elderly age and comorbidites impact on survival, making bone marrow transplantation only rarely possible. Patients are usually treated with supportive care or mild cytoreductive therapy, like hydroxyurea or low dose cytarabine, until leukemic evolution. In the era of epigenetics, the possibilities offered by the new molecular targeted therapies offer the chance of modifying the natural history of this disease. Among these, the hypomethylating agents Azacitidine and Decitabine have been shown to induce responses in CMML patients. Azacytidine is mostly incorporated into RNA and reaches DNA following reduction by ribonucleotide reductase, while decitabine is directly incorporated into DNA. Both drugs have been shown to produce a direct decrease of DNA methyltransferase 
Table 1. Patients' Characteristics

\begin{tabular}{|c|c|c|c|}
\hline & Patient 1 & Patient 2 & Patient 3 \\
\hline $\begin{array}{l}\text { Counts at diagnosis } \\
\mathrm{Hb}(\mathrm{g} / \mathrm{dl}) \\
\text { WBC }\left(10^{9} / \mathrm{L}\right) \\
\text { Monocytes }\left(10^{9} / \mathrm{L}\right) \\
\text { PLTS }\left(10^{9} / \mathrm{L}\right) \\
\text { BM-blasts }(\%)\end{array}$ & $\begin{array}{c}9.9 \\
19.4 \\
6.5 \\
55 \\
11\end{array}$ & $\begin{array}{c}12 \\
10.5 \\
3 \\
77 \\
15\end{array}$ & $\begin{array}{c}8 \\
9.4 \\
4 \\
178 \\
9\end{array}$ \\
\hline $\begin{array}{l}\text { Counts after } 4 \text { AZA cycles } \\
\mathrm{Hb}(\mathrm{g} / \mathrm{dl}) \\
\text { WBC }\left(10^{9} / \mathrm{L}\right) \\
\text { Monocytes }\left(10^{9} / \mathrm{L}\right) \\
\text { PLTS }\left(10^{9} / \mathrm{L}\right) \\
\text { BM-blasts }(\%)\end{array}$ & $\begin{array}{c}13.3 \\
7.09 \\
0.68 \\
86 \\
2.5\end{array}$ & $\begin{array}{c}11.2 \\
6.03 \\
1.03 \\
84 \\
3.5\end{array}$ & Progression \\
\hline $\begin{array}{l}\text { Counts after } 8 \text { AZA cycles } \\
\text { Hb }(\mathrm{g} / \mathrm{dl}) \\
\text { WBC }\left(10^{9} / \mathrm{L}\right) \\
\text { Monocytes }\left(10^{9} / \mathrm{L}\right) \\
\text { PLTS }\left(10^{9} / \mathrm{L}\right) \\
\text { BM-blasts }(\%)\end{array}$ & $\begin{array}{c}12.9 \\
5.72 \\
0.70 \\
74 \\
5\end{array}$ & $\begin{array}{c}11.2 \\
4.09 \\
1.5 \\
56 \\
2\end{array}$ & Progression \\
\hline
\end{tabular}

AZA: 5-azacytidine (Vidaza, Celgene ${ }^{\mathrm{TM}}$ ), Hb: hemoglobin; WBC: white blood cells; PLTS: platelets; BM-Blast: bone marrow blast counts

activity in vitro and in vivo, reverting aberrant DNA methylation and increasing the expression of silenced genes, leading to cellular differentiation and/or apoptosis. ${ }^{3-4}$ Furthermore a direct cytotoxic effect has been shown in cell lines treated with decitabine, partially explaining the lack of correlation between degree of demethylation and response. ${ }^{3-4}$

Case Report: We treated 3 CMML-2 patients (2 men and 1 woman) of a median age of 63 years (range 5469), and IPSS intermediate-2/high (normal caryotype, 1 or two cytopenias and $9-15 \%$ bone marrow blasts)(Table 1). Patients were treated with 5azacitidine (Vidaza, Celgene ${ }^{\mathrm{TM}}$ ) at $75 \mathrm{mg} / \mathrm{mq}$ for 7 days at 14.2, 21.6 and 4 months from initial diagnosis. After 4 cycles of azacitidine, 2 patients achieved partial response and are in continuous partial response, with stable peripheral blood counts (Table 1) at 29 and 30 cycles from treatment start and at 36 and 50 months from disease onset. Treatment has been well tolerated, with only mild gastrointestinal and cutaneous toxicity (WHO grade 1). One 54 year-old patient, after a transient response to 5-Azacitidine with normalization of peripheral blood counts, progressed to AML after 4 cycles, underwent allogenic bone marrow transplantation and died for systemic infection at 12 months from CMML diagnosis. During the first azacitidine cycle, this patient had developed a long period of pancytopenia, complicated by acute respiratory distress due to Aspergillus pneumonia, which recovered following anti-fungal treatment. AML progression was characterized by hyperleukocytosis and acquisition of cytogenetic abnormalities. In this patient, younger age, low hemoglobin levels and high peripheral blood monocyte counts at CMML onset, were unfavourable prognostic factors, according to CMML stratified risk assessment. ${ }^{6}$

Discussion: Efficacy of Azacitidine and Decitabine in the treatment of MDS has been confirmed by several national and international clinical trials although a protocol comparing efficacy of the two drugs has not been performed yet. These studies demonstrated efficacy of hypomethylating agents compared to best supportive care..$^{7-8}$ Azacitidine in particular, significantly prolonged median time to progression to acute myeloid leukemia or death and prolonged median overall survival compared with conventional care regimens. ${ }^{9-12}$ Hypomethylating agents have been only rarely used in CMML and there are no prospective studies with sufficient patient numbers in this disease.

A study by the MD Anderson reported the use of decitabine in 19 elderly CMML patients, with encouraging results, with achievement of $58 \%$ complete remission (CR) and $11 \%$ hematological improvement (HI), resulting into an overall response rate of $69 \% .^{13} \mathrm{~A}$ retrospective review analyzing four phase 3 and phase 2 trials in CMML patients demonstrated $25 \%$ overall response rate $(\mathrm{CR}+\mathrm{PR})$, with additional $11 \% \mathrm{HI}$ and $39 \%$ stable disease, confirming the superiority of decitabine over best supportive care. Tolerability was good, non hematologic side effects were minimal and myelosuppression-associated complications were acceptable. ${ }^{14}$ A recent paper on 38 CMML treated with Azacitidine at $75 \mathrm{mg} / \mathrm{mq} / \mathrm{day}$ for 7 days or 100 
$\mathrm{mg} / \mathrm{mq} /$ day for 5 days every 4 weeks, reported $39 \%$ overall response rate, with $11 \%$ CR, 3\% PR and $25 \%$ $\mathrm{HI}$ resulting into a median overall survival of 12 months. ${ }^{15}$ The median number of cycles given to achieve response was 2 , with a median short duration of response of 6.5 months (range, 3 to over 50 months). Incorporation of azacitidine into DNA makes its effect S-phase dependent and requires two or more cycles of DNA synthesis to alter gene transcription and expression. Azacitidine also acts as a biologic response modifier exerting a cytotoxic effect on regulatory $\mathrm{T}$ cells or other modulatory cells which may inhibit hematopoiesis in MDS. Thus, the response is subjective and three to four treatment cycles are necessary before the effect becomes clinically apparent. Moreover, the issue of the best treatment

\section{References:}

1. Bennett JM, Catovsky D, Daniel MT, et al. Proposals for the classification of the acute leukaemias. French-American-British (FAB) co-operative group. Br J Haematol 1976.

2. SwerdlowSH,CampoE,HarrisNLet al. WHO Classification of Tumours of Haematopoietic and Lymphoid Tissues Lyon: IARC Press, 2008.

3. Fabiani E, Leone G, Giachelia M, D'alo' F, Greco M, Criscuolo M, Guidi F, Rutella S, Hohaus S, Voso MT. Analysis of genome-wide methylation and gene expression induced by 5 aza-2'-deoxycytidine identifies BCL2L10 as a frequent methylation target in acute myeloid leukemia. Leuk Lymphoma. 2010 Dec;51(12):2275-84. Epub 2010 Nov 15 doi:10.3109/10428194.2010.528093 PMid:21077739

4. Flotho C, Claus R, Batz C, Schneider M, Sandrock I, Ihde S, Plass C, Niemeyer CM, Lübbert M. The DNA methyltransferase inhibitors azacitidine, decitabine and zebularine exert differential effects on cancer gene expression in acute myeloid leukemia cells. Leukemia. 2009 Jun;23(6):1019-28. Epub 2009 Feb 5. doi:10.1038/leu.2008.397 PMid:19194470

5. Silverman LR, Fenaux P, Mufti GJ, Santini V, HellströmLindberg E, Gattermann N, Sanz G, List AF, Gore SD, Seymour JF. Continued azacitidine therapy beyond time of first response improves quality of response in patients with higher-risk myelodysplastic syndromes. Cancer. 2011 Jan 10. [Epub ahead of print]

6. Fenaux P, Beuscart R, Lai JL, Jouet JP, Bauters F. Prognostic factors in adult chronic myelomonocytic leukemia: an analysis of 107 cases. J Clin Oncol. 1988 Sep;6(9):1417-24. PMid:3166485

7. Kantarjian H, Issa JP, Rosenfeld CS, Bennett JM, Albitar M, DiPersio J, Klimek V, Slack J, de Castro C, Ravandi F, Helmer R 3rd, Shen L, Nimer SD, Leavitt R, Raza A, Saba H. Decitabine improves patient outcomes in myelodysplastic syndromes: results of a phase III randomized study. Cancer. $2006 \mathrm{Apr}$ 15;106(8):1794-803 doi:10.1002/cncr.21792 PMid:16532500

8. Voso MT, Santini V, Finelli C, Musto P, Pogliani E, Angelucci E, Fioritoni G, Alimena G, Maurillo L, Cortelezzi A, Buccisano F, Gobbi M, Borin L, Di Tucci A, Zini G, Petti MC, Martinelli G, Fabiani E, Fazi P, Vignetti M, Piciocchi A, Liso V, Amadori $\mathrm{S}$, Leone G. Valproic acid at therapeutic plasma levels may increase 5-azacytidine efficacy in higher risk myelodysplastic syndromes. Clin Cancer Res. 2009 Aug 1;15(15):5002-7. doi:10.1158/1078-0432.CCR-09-0494 PMid:19638460 schedule is still controversial. Costa et al, tested a dose of $100 \mathrm{mg} / \mathrm{mq} / \mathrm{day}$ for 5 consecutive days considering this approach more convenient and equal in efficacy. ${ }^{15}$ Todate there are no specific indications on the best treatment schedule in CMML. Due to reversibility of hypomethylating agents effects and to the lack of eradication of the malignant clone, treatment should be continued until response persists. ${ }^{16}$

Our findings confirm highly favorable response rates to azacitidine therapy in high-risk CMML patients, encouraging the application of the treatment in this subset of patients. A correct risk assessment requires the identification of new molecular and clinical features predictive of reponse to hypomethylating agents, to make an effective patienttargeted approach feasible.

9. Fenaux P, Mufti GJ, Hellstrom-Lindberg E, Santini V, Finelli C, Giagounidis A, Schoch R, Gattermann N, Sanz G, List A, Gore SD, Seymour JF, Bennett JM, Byrd J, Backstrom J, Zimmerman L, McKenzie D, Beach C, Silverman LR; International Vidaza High-Risk MDS Survival Study Group. Efficacy of azacitidine compared with that of conventional care regimens in the treatment of higher-risk myelodysplastic syndromes: a randomised, open-label, phase III study.Lancet Oncol. 2009 Mar;10(3):223-32. doi:10.1016/S1470-2045(09)70003-8

10. Silverman LR, McKenzie DR, Peterson BL, Holland JF, Backstrom JT, Beach CL, Larson RA; Cancer and Leukemia Group B. Further analysis of trials with azacitidine in patients with myelodysplastic syndrome: studies 8421, 8921, and 9221 by the Cancer and Leukemia Group B. J Clin Oncol. 2006 Aug 20;24(24):3895-903 PMid:16921040 doi:10.1200/JCO.2005.05.4346

11. Seymour JF, Fenaux P, Silverman LR, Mufti GJ, HellströmLindberg E, Santini V, List AF, Gore SD, Backstrom J, McKenzie D, Beach CL. Effects of azacitidine compared with conventional care regimens in elderly ( $\geq 75$ years) patients with higher-risk myelodysplastic syndromes. Crit Rev Oncol Hematol. $2010 \quad$ Dec;76(3):218-27. doi:10.1016/j.critrevonc.2010.04.005 PMid:20451404

12. Voso, M., D'alò, F., Greco, M., Criscuolo, M. new treatments for myelodysplastic syndromes. Mediterr J Hematol Infect Dis,

2010, 2(2): e2010021, doi:10.4084/MJHID.2010.021 Available at: http://www.mjhid.org/article/view/6072.

13. Aribi A, Borthakur G, Ravandi F, Shan J, Davisson J, Cortes J, Kantarjian H. Activity of decitabine, a hypomethylating agent, in chronic myelomonocytic leukemia. Cancer. 2007 Feb 15;109(4):713-7. doi:10.1002/cncr.22457 PMid:17219444

14. Wijermans PW, Rüter B, Baer MR, Slack JL, Saba HI, Lübbert M. Efficacy of decitabine in the treatment of patients with chronic myelomonocytic leukemia (CMML). Leuk Res. 2008 Apr;32(4):587-91 이:10.1016/j.leukres.2007.08.004 PMid:17881052

15. Costa R, Abdulhaq H, Haq B, Shadduck RK, Latsko J, Zenati M, Atem FD, Rossetti JM, Sahovic EA, Lister J. Activity of azacitidine in chronic myelomonocytic leukemia. Cancer. 2010 Dec 23. [Epub ahead of print] PMID: 21184518

16. Silverman LR, Demakos EP, Peterson BL, Kornblith AB, Holland JC, Odchimar-Reissig R, Stone RM, Nelson D, Powell BL, DeCastro CM, Ellerton J, Larson RA, Schiffer CA, Holland JF. Randomized controlled trial of azacitidine in patients with the myelodysplastic syndrome: a study of the cancer and leukemia group B. J Clin Oncol. 2002 May 15;20(10):2429-40. doi:10.1200/JCO.2002.04.117 PMid:1201112 